\title{
РЕЗУЛЬТАТИ ДОСЛІДЖЕННЯ ПСИХОЛОГІЧНОЇ ГОТОВНОСТІ КЕРІВНИКІВ ОПЕРАТИВНО-РОЗШУКОВИХ ПІДРОЗДІЛІВ ДО УПРАВЛІННЯ ОРГАНІЗАЦІЙНИМИ ЗМІНАМИ
}

УДК: 159.922 .6

\section{Туз Олександр Сергійович}

Викладач кафедри спеціальних дисциплін Національної академї Державної прикордонної служби Украйни імені Богдана Хмельницького, м. Хмельницуький (Украӥна)

ORCID ID: https://orcid.org/0000-0003-3879-4013

\begin{abstract}
Анотація. $\quad$ у статті викладено результати емпіричного дослідження рівня психологічної готовності керівників оперативно-розшукових підрозділів Державної прикордонної служби України до управління організаційними змінами. Психологічну готовність було досліджено за показниками сформованості когнітивного, мотиваційного, особистісного, діяльнісного та регулятивного компонентів. Виявлено, щуо переважна більшість респондентів має особистісні якості, які сприяють їх високій готовності до управління організаційними змінами. Наведено результати факторного аналізу, який дозволив виділити три фактори що характеризують основні типові прояви психологічної готовності керівників оперативнорозшукових підрозділів до управління змінами та результати кластерного аналізу, за допомогою якого виділено п'ять типів ї̈ прояву. Встановлено залежність між службовим досвідом керівників оперативно-розшукових підрозділів та рівнем їх психологічної готовності до управління організаційними змінами.
\end{abstract}

Ключові слова: психологічна готовність, організаційні зміни, керівник оперативнорозиукового підрозділу, службовий досвід.

Постановка проблеми у загальному вигляді та їі зв'язок із важливими науковими чи практичними завданнями.

Останнім часом оперативно-розшукові органи і підрозділи перебувають у стані постійних організаційних змін, які викликані не- обхідністю адекватного реагування на посилення загроз та ризиків у сфері прикордонної безпеки України. Безпрецедентна всебічність, глибина, комплексність і темп технологічних, соціальних і інших змін, які відбуваються в оперативно-розшукових органах та підрозді- 
лах ставлять на перше місце проблему психологічної готовності керівників до ефективного управління змінами в організації та управлінні оперативно-розшуковою діяльністю на кордоні. Водночас, стан психологічної готовності керівників до управління організаційними змінами до цього часу спеціально не досліджувався, що робить його вивчення важливим завданням науково-прикладного характеру.

Аналіз останніх досліджень і публікацій, в яких започатковано вирішення даної проблеми та на які опирається автор. 3 початком XXI століття вітчизняні психологи стали приділяти значну увагу проблемі функціонування організації в умовах сучасних трансформацій [1-5]. У монографії колективу лабораторії соціальної та організаційної психології Інституту психології ім. Г. С. Костюка висвітлено низку актуальних теоретичних та практичних питань [1]. Зокрема, авторами визначено сутність організаційного розвитку та основні підходи до дослідження зазначеного феномену. На прикладі освітніх організацій проаналізовано особливості організаційного розвитку, виділено основні психологічні чинники та умови організаційного розвитку, запропоновано тренінг для підготовки персоналу до психологічного забезпечення організаційного розвитку. Для нашого дослідження важливою є теза про те, що організаційний розвиток - це, скоріше, техніка, що використовується для здійснення організаційних змін 3 метою підвищення ефективності іiі діяльності [1, с. 11]. Зазна- чене дає нам підстави розглядати управління організаційними змінами в якості складової організаційного розвитку, а вдосконалення управління змінами однією із запорук позитивного впливу на ефективність організаційної діяльності.

Основні підходи до визначення поняття «управління змінами в організації» проаналізовано в роботі Л. М. Карамушки та М. В. Москальова [2]. В дослідженні подано авторський підхід до визначення та обгрунтування змісту і структури психологічної готовності майбутніх менеджерів до управління змінами в організації, наведено результати емпіричного дослідження чинників, що впливають на їі становлення, наголошено на проблемах, які існують у психологічній підготовці майбутніх керівників до управління змінами в організації. Проаналізовано взаємозв'язок між типами структури психологічної готовності майбутніх менеджерів та низкою соціальнодемографічних та організаційно-професійних чинників. Викладені у монографії положення щодо організації дослідження дали змогу визначити основні напрями дослідження психологічної готовності до управління організаційними змінами керівників оперативнорозшукових підрозділів.

Аналіз наукової літератури з проблеми управління організаційними змінами був би не повним без звернення до дослідження психології діяльності організацій в умовах соціально-економічних змін [4]. Саме соціально- 
економічні зміни визначальним чином впливають на зовнішнє середовище організацій, що, в свою чергу, спонукає їх до запровадження організаційних змін спрямованих на встановлення рівноваги внутрішнього та зовнішнього середовища організації та збереження ії ефективності.

Прикладний аспект роботи 3 персоналом, у тому числі, керівниками грунтовно висвітлений у навчальному посібнику з технології психологічної підготовки персоналу освітніх організацій до роботи в умовах соціальноекономічних змін [5]. Викладений у навчальному посібнику технологічний підхід до психологічної підготовки персоналу до діяльності в умовах організаційних змін може бути ефективно застосований не лише в освітніх організаціях, особливо це стосується опису основних видів психолого-управлінських технологій та інтерактивних технік, які використовуються в процесі реалізації технологічного підходу.

Можна навести низку інших досліджень 3 проблеми психологічної підготовки керівників до діяльності в умовах організаційних змін. Зокрема, це робота А. С. Короля, який досліджував психологічну готовність до управління змінами керівників прикордонного відомства різного управлінського рівня [6]. Робота О. І. Бондарчук, у якій наведені результати дослідження психологічної підготовки керівників освітніх організацій до діяльності в умовах змін [7]. Дослідження О. А. Філь, яка розробила технологію психологічної підготовки керівників до забезпечення конкурентоздатності освітніх організацій в умовах змін [8] та інші.

Таким чином, вітчизняними науковцями напрацьовано загальний методичний підхід до вивчення проблеми психологічної готовності керівників до управління змінами та значний емпіричний матеріал. Проте, результати проаналізованих нами досліджень не дозволяють визначити рівень психологічної готовності керівників саме оперативно-розшукових підрозділів до управління організаційними змінами. Водночас, останні роки значення оперативно-розшукової складової у забезпеченні прикордонної безпеки країни постійно зростає і потребує пошуку науково обгрунтованих шляхів іiї підвищення.

Метою дослідження $є$ визначення наявного рівня психологічної готовності керівників оперативно-розшукових підрозділів до управління організаційними змінами на основі аналізу результатів емпіричного дослідження іiї компонентів.

Виклад основного матеріалу дослідження 3 повним обгрунтуванням отриманих наукових результатів. Структура психологічної готовності керівника до управління організаційними змінами складається 3 когнітивного, мотиваційного, особистісного, діяльнісного та регулятивного компонентів, які відображають: систему знань, умінь та навичок управління в умовах організаційних змін, по- 
єднану з інформованістю про зміст змін, життєвим та службовим досвідом; мотивацію до ефективної реалізації управлінських завдань в умовах організаційних змін та уявлення про можливість задоволення професійних, кар'єрних, особистісних (у т. ч. матеріальних) потреб у разі успішного проведення організаційних змін; рефлексію на власне ставлення до організаційних змін, процес та результати власної діяльності, самоконтроль і самооцінку власної готовності до управління організаційними змінами, здатність до розуміння власних помилок та корегування особистісної позиції щодо організаційних змін та управління ними.
Рівень психологічної готовності керівників оперативно-розшукових підрозділів до управління організаційними змінамивизначався на основі аналізу сформованості кожного 3 іiї компонентів (див. Табл. 1).

Рівень розвитку когнітивного компоненту аналізувався за показниками сформованості рівня професійних знань, умінь і навичок керівників оперативно-розшукових підрозділів $з$ управління в умовах організаційних змін. Аналіз результатів свідчить, що керівники мають недостатній рівень професійної обізнаності із зазначеної проблеми. Найбільші труднощі у керівників оперативно-розшукових підрозді-

Таблиия 1.

\section{Сформованість компонентів психологічної готовності керівників оперативно-розшукових підрозділів}

\begin{tabular}{|c|c|c|c|c|c|c|}
\hline & \multicolumn{6}{|c|}{ Рівень сформованості: } \\
\hline & осіб & $\%$ & ocí̄ & $\%$ & осіб & $\%$ \\
\hline \multicolumn{7}{|c|}{ Когнітивний компонент } \\
\hline Рівень професійних знань & 27 & 12,22 & 129 & 58,37 & 65 & 29,41 \\
\hline $\begin{array}{l}\text { Рівень умінь та навичок управління в умовах } \\
\text { організаційних змін }\end{array}$ & 17 & 7,69 & 148 & 66,97 & 56 & 25,34 \\
\hline Інтегральний показник & \multicolumn{6}{|c|}{$\mathbf{1 , 8 3}$} \\
\hline \multicolumn{7}{|c|}{ Мотиваційний компонент } \\
\hline Рівень мотивації вибору професії & 58 & 26,25 & 126 & 57,01 & 37 & 16,74 \\
\hline Рівень мотивації досягнення успіху & 64 & 28,96 & 116 & 52,49 & 41 & 18,55 \\
\hline Рівень мотивації уникнення невдач & 49 & 22,17 & 118 & 53,39 & 54 & 24,43 \\
\hline Інтегральний показник & \multicolumn{6}{|c|}{2,05} \\
\hline \multicolumn{7}{|c|}{ Діяльнісний компонент } \\
\hline Рівень глобального мислення & 21 & 9,50 & 140 & 63,35 & 60 & 27,15 \\
\hline Інтегративний показник & \multicolumn{6}{|c|}{1,82} \\
\hline \multicolumn{7}{|c|}{ Особистісний компонент } \\
\hline Рівень самооцінки & 61 & 27,60 & 152 & 68,78 & 8 & 3,62 \\
\hline Рівень спрямованості особистості & 64 & 28,96 & 145 & 65,61 & 12 & 5,43 \\
\hline Інтегративний показник & \multicolumn{6}{|c|}{2,24} \\
\hline \multicolumn{7}{|c|}{ Регулятивний компонент } \\
\hline Рівень саморегуляції психічної стійкості & 132 & 59,73 & 69 & 31,22 & 20 & 9,05 \\
\hline
\end{tabular}


лів викликали відповіді на запитання щодо змісту професійних завдань; психологічних особливостей управління; вимог до особистості керівника; якостей, що необхідні для управління організаційними змінами. 3 таблиці1 видно, що професійні знання більшості керівників перебувають на середньому $(58,37 \%)$ та низькому $(29,41 \%)$ рівнях. Високий рівень професійних знань продемонструвала невелика кількість керівників (12,22\%). Отже, отримані результати вказують на недостатню професійну обізнаність керівників оперативнорозшукових підрозділів щодо сутності організаційних змін, особливостей управління ними в оперативно-розшукових органах Державної прикордонної служби України та необхідність iї вдосконалення.

Вимірювання рівня розвиненості умінь та навичок управління в умовах організаційних змін засвідчило, що більшість керівників оперативно-розшукових підрозділів мають середній рівень розвитку умінь та навичок необхідних для управління в умовах організаційних змін (66,97\%). Слабкі уміння та навички управління в умовах організаційних змін діагностовано у $25,34 \%$ опитаних, при тому, що високий рівень виявлено лише у 7,69\% офіцерів. В індивідуальних бесідах з офіцерами у яких було діагностовано слабкий рівень знань, умінь та навичок з управління організаційними змінами в організації відмітили відсутність подібної теми у навчальних курсах Національної академії Державної прикордонної служби
України ім. Богдана Хмельницького, відсутність можливостей до самостійного вивчення наукової та науково-популярної літератури 3 менеджменту, незалежність характеру та змісту організаційних змін, що вони реалізують від їх точки зору і сувору регламентацію оперативно-розшукової та управлінської діяльності у прикордонному відомстві.

Рівень сформованості мотиваційного компоненту психологічної готовності керівників оперативно-розшукових органів до управління організаційними змінами визначався за результатами діагностування мотивів вибору професії, мотивації на досягнення успіху та мотивації на уникнення невдач. Дані наведені у таблиці1 свідчать що мотиви вибору професії сформовані у керівників оперативнорозшукових підрозділів переважно на середньому рівні (57,01\%). Це дає підстави стверджувати, що більшість офіцерів-розвідників під час вибору професії керувалися передусім соціально-значущими мотивами (розмір грошового утримання, престиж професії, кар'єрне зростання, соціальний статус, тощо). Понад чверть керівників оперативно-розшукових підрозділів (26,25\%) обирали професію виходячи з її соціального значення, бажання бути корисним суспільству, тощо (високий рівень мотивації). Водночас у значної кількості офіцерів (16,74\%)мотивація вибору професії виявилася на низькому рівні, вони стали оперативними працівниками під впливом батьків, друзів та інших обставин, що не по'вязані з соціальною 
важливістю обраної справи.

Зроблені висновки було підтверджено результатами контент-аналізу відповідей на додаткові запитання анкети. Зокрема, керівники оперативно-розшукових підрозділів керувалися при виборі професії такими мотивами: втілення власних потреб (61,09\%), матеріальний статок (20,81\%), отримання владних повноважень $(9,05 \%)$, вплив інших людей (6,33\%). Зазначене свідчить про відсутність у багатьох керівників оперативно-розшукових підрозділів внутрішніх орієнтирів при виборі професії. Таким чином, можна очікувати що недостатня вмотивованість до якісного виконання своїх службових обов'язків може негативно вплинути на готовність до вирішення проблем, що виникають в управлінні організаційними змінами.

Щодо спрямованості мотивації керівників оперативно-розшукових підрозділів на досягнення успіху,то результати тестування свідчать, що у переважної більшості респондентів цей показник перебуває на середньому $(52,49 \%)$ та високому $(28,96 \%)$ рівнях. Проте, слід відзначити суттєву кількість офіцерів, які на досягнення успіху не вмотивовані (18,55\%).

Відносно спрямованості мотивації керівників оперативно-розшукових підрозділів на уникнення невдач, то отримані результати розподілилися таким чином: найбільша кількість респондентів потрапила до групи із середнім рівнем сформованості цього мотиву $(53,39 \%)$; другу групу склали респонденти, які показали низький рівень мотивації на уникнення невдач (24,43\%). Приблизно така ж кількість офіцерів продемонструвала високий рівень сформованості цього виду мотивації (22,17\%). На основі отриманих даних можна зробити висновок про те, що більшість керівників оперативнорозшукових підрозділів мають середній рівень мотивації як на досягнення успіху, так і на уникнення невдач. За таких обставин значна кількість керівників оперативно-розшукових підрозділів відчуває труднощі при формуванні особистої позиції щодо організаційних змін, може несвоєчасно приймати необхідні управлінські рішення в умовах змін.

Дослідженням виявлено, що тенденція прагнення до успіху є складною функцією трьох змінних: мотиву прагнення до успіху, суб'єктивної вірогідності досягнення успіху, його привабливості в даній ситуації. Мотив прагнення до успіху - це стійка диспозиція особистості переживати гордість і задоволення при досягненні успіху. Тенденція уникнення невдач є мультиплікаційною функцією мотиву уникнення невдачі (прагнення уникнути невдачі та сорому) та її привабливості в певній ситуації [9]. В цілому, результати дослідження мотиваційного компоненту психологічної готовності керівників оперативно-розшукових підрозділів до управління організаційними змінами вказують на їх певну мотиваційну незрілість.

Діяльнісний компонент психологічної готовності керівників оперативно-розшукових 
підрозділів до управління організаційними змінами досліджувався за допомогою методики оцінки глобального управлінського потенціалу. Дослідження рівня сформованості глобальності мислення керівників оперативнорозшукових підрозділів показало, що у 63,35\% опитаних, тобто переважної більшості офіцерів, виявлено середній рівень сформованості даної особистісної якості, яка визначає ставлення до необхідності організаційних змін. Ще у 27,15\% - середній рівень, і лише у $9,50 \%$ - високий рівень. Отриманий результат свідчить про недостатню психологічну готовність керівників оперативно-розшукових підрозділів сприймати організаційні зміни у прикордонному відомстві у контексті глобалізації та кращих зразків функціонування прикордонних відомств США та Європи.

Щодо результатів діагностування особистісного компоненту психологічної готовності керівників оперативно-розшукових підрозділів до управління організаційними змінами, то аналіз результатів, які характеризують рівень сформованості спрямованості особистості, свідчить що в цілому понад 96,38\% респондентів мають адекватну самооцінку. Такі керівники реально оцінюють власну особистість, здатні переживати позитивні почуття стосовно самих себе, можуть прийняти себе такими яким вони $\epsilon$, як 3 позитивними, так і 3 негативними якостями. Їм притаманні впевненість у собі, у своїх діях, у тому, що життєві та професійні труднощі можна подолати, адеква- тне сприйняття критики, прихильне та доброзичливе ставлення до людей, відчуття задоволення собою та наявність сприятливих життєвих перспектив. Що стосується рівня сформованості спрямованості особистості у більшої частини опитаних керівників $(65,61 \%)$ цей показник відповідає середньому рівню, ще $28,96 \%$ опитаних мають високий рівень і 5,43\%- низький.

Рівень сформованості регулятивного компоненту психологічної готовності керівників оперативно-розшукових підрозділів до організаційних змін виявлявся за результатами визначення стилю саморегуляції психічної стійкості.Як свідчать результати дослідження, рівень саморегуляції психічної стійкості більшості керівників оперативно-розшукових підрозділів відповідає середньому рівню60,18\%,другу за кількістю групу становлять керівники з високим рівнем саморегуляції $36,65 \%$ третю з низьким $-3,17 \%$.

Дослідження рівня сформованості регулятивного компоненту психологічної готовності керівників оперативно-розшукових підрозділів до управління організаційними змінами супроводжувалося визначенням регуляторного профілю, що характеризує індивідуальний рівень розвитку основних регуляторних механізмів, які забезпечують функціональні ланки цілісної системи саморегуляції. B. I. Моросанова виокремлює два типи профілів саморегуляції: гармонійний («гладкий»), якому відповідає приблизно однакова розви- 
неність

основних

процесів

та «акцентований» («шпилястий»), якому відповідає різний ступінь сформованості регуляторних ланок. Ефективність того чи іншого профілю залежить від рівня розвиненості регуляторних ланок та наявності між ними компенсаторного зв'язку. Якщо регуляторні ланки слаборозвинені або немає компенсаторного зв'язку між добре розвиненими та малорозвиненими регуляторними ланками, профіль саморегуляції виявляється неефективним [9].

Аналіз отриманих даних свідчить про наявність трьох типів ефективного профілю саморегуляції психічної стійкості у керівників оперативно-розшукових підрозділів. Ефективного рівня саморегуляції досягають керівники 3 високим рівнем розвиненості переважної більшості регуляційних ланок; 3 приблизно однаковою кількістю піків високого та середнього рівня; з наявністю у профілі показників низького рівня, при обов'язковій присутності показників високого рівня. Нами практично не виявлено профілів з низьким рівнем розвиненості всіх ланок. Взагалі низькі показники зустрічаються дуже рідко, і завжди поряд з високим та середнім рівнями розвитку інших ланок. Отримані нами результати дають підстави стверджувати про наявність відповідних компенсаторних механізмів у процесах саморегуляції психічної стійкості керівників оперативно-розшукових підрозділів.

Таким чином, керівникам оперативнорозшукових підрозділів, які взяли участь у на- шому дослідженні, в цілому притаманний високий рівень свідомого планування та програмування власної діяльності, адекватність в оцінюванні результатів дій, відсутність фіксації на невдачах, високий рівень гнучкості, швидке орієнтування в ситуації, стійкість і здатність не губитися в умовах невизначеності, творчість у підходах до розв'язання нетипових ситуацій, середній рівень самостійності, постійні зв'язки, контакти з керівництвом, наполегливість у досягненні власних цілей, точність і своєчасність у корекції власних помилок. Такий рівень саморегуляції психічної стійкості керівників слід розглядати як основу для відносно легкого подолання ними психологічних бар'єрів і змінювання особистісної позиції щодо організаційних змін на більш позитивну.

Для порівняння структурних компонентів психологічної готовності керівників оперативно-розшукових підрозділів до управління організаційними змінами було використано методику системно-структурного аналізу складних об'єктів (В. А. Семиченко) [10].Отримані дані було сформовано за інтегральними показниками компонентів психологічної готовності за рівнями. Це дало змогу визначити узагальнений інтегральний показник компонентів психологічної готовності керівників оперативно-розшукових підрозділів до управління організаційними змінами. Рівень сформованості різних структурних компонентів психологічної готовності керівників 
оперативно-розшукових підрозділів до управління організаційними змінами не однаковий. Так, найбільш розвиненими постають регулятивний та особистісний компоненти $-2,51$ та 2,24 бали відповідно, на середньому рівні розвинений мотиваційний компонент - 2,05 бали, на рівні нижче середнього - когнітивний та діяльнісний компоненти - 1,83 та 1,82 бали відповідно. Слід відзначити, що в цілому психологічна готовність керівників оперативнорозшукових підрозділів до управління організаційними змінами перебуває на середньому рівні - 2,09 балу з 3 можливих. I якщо рівень розвиненості регулятивного компоненту можна вважати задовільним, то інші компоненти потребують подальшого розвитку. Особливо це стосується мотиваційного, когнітивного та діяльнісного компонентів.

Такий розподіл між компонентами психологічної готовності можна пояснити тим, що управлінська діяльність і оперативнорозшукова діяльність 3 охорони державного кордону в цілому пред'являють підвищені вимоги до рівня саморегуляції керівників оперативно-розшукових підрозділів. Тому у процесі навчання та служби у них формуються і відповідні уміння та навички саморегуляції. Водночас, розроблена нами модель психологічної готовності керівників оперативно-розшукових підрозділів до управління організаційними змінами та отримані емпіричні результати, дозволяють стверджувати, що рівень розвитку когнітивного компоненту впливає на стан мо- тиваційного компоненту. I хоча процеси вироблення керівником оперативно-розшукового підрозділу особистої позиції щодо організаційних змін складні та неоднозначні, можна стверджувати, що, чим більше у керівника інформації про сутність, зміст організаційних змін, плани щодо їх реалізації та очікувані результати, тим простіше сформувати у нього позитивне ставлення до них.

Наступним етапом нашого дослідження стала структурна типізація психологічної готовності керівників оперативно-розшукових підрозділів до управління організаційними змінами. 3 цією метою було проведено факторний аналіз отриманих даних. За його результатами було виділено три фактори які охоплюють 64,46\% загальної дисперсії і характеризують основні типові прояви психологічної готовності. До першого фактору, який отримав назву «схильність до змін», було віднесено такі складові: «здатність гнучко і творчо діяти в умовах змін» $(0,742)$; «рівень професійних i управлінських знань» $(0,733)$; «здатність вирішувати ситуативні завдання» (0,692); «глобальність мислення» $(0,674)$. Фактор охоплює 24,66\% загальної дисперсії. До другого фактору, який отримав назву «налаштованість на зміни», було віднесено такі характеристики: «зовнішні позитивні мотиви» $(0,756)$, «внутрішні значущі мотиви» $(0,688)$, «зовнішні негативні мотиви» $(0,656)$; «мотивація досягнення успіху» $(0,611)$, «мотивація уникнення невдач» $(0,521)$. Фактор 
охоплює 20,62\% загальної дисперсії. До третього фактору, який отримав назву «адаптованість до змін», було віднесено: «оперативність програмування управлінських дій» (0,702); «стійкість оціночних процесів» $(0,676)$; «самостійність цілепокладання» $(0,532)$. Фактор охоплює $18,36 \%$ загальної дисперсії. Для кожного з виділених факторів було визначено основні психологічні характеристики керівників ОРП.

За результатами факторного аналізу було проведено кластерний аналіз, що дозволило типізувати структуру психологічної готовності керівників оперативно-розшукових підрозділів до управління організаційними змінами. Було виділено п'ять типів особистості керівників: «дієвий», «вмотивований», «активний», «пасивний» та «ригідний».За результатами діагностування найбільше керівників оперативно-розшукових підрозділів належить до «дієвого» типу - 33\%; до типу «вмотивований» - 26\%; типу «активний» $18 \%$; до «пасивного» типу - 17\%, «ригідного» типу - 6\%.Так як представників «дієвого» та «вмотивованого» типів керівників оперативно-розшукових підрозділів можна віднести до осіб, які мають найбільш високий рівень психологічної готовності до управління організаційними змінами, то слід відзначити, що значна їх частина (59\%) мають високий рівень психологічної готовності до управління змінами. Керівники оперативно-розшукових підрозділів, яких було віднесено до інших типів потре- бують вжиття до них додаткових заходів як теоретичного так і практичного характеру, що будуть спрямовані на підвищення рівня їх теоретичних знань, вдосконалення умінь та навичок управління, корегування мотиваційних чинників та способів саморегуляції діяльності. 3 результатів теоретичного аналізу проблеми випливає залежність психологічної готовності керівників оперативно-розшукових підрозділів до управління організаційними змінами від наявного у керівника службового досвіду (тривалість служби у прикордонному відомстві взагалі та в Оперативнорозшуковому департаменті Адміністрації Державної прикордонної служби України зокрема). Найвищий рівень психологічної готовності до управління організаційними змінами виявлений у керівників із службовим досвідом від 5 до 10 років.

Слід відзначити, що зазначені дані частково збігаються 3 результатами, які було отримано А. С. Королем у 2013 році у дослідженні психологічної готовності до організаційних змін керівників Державної прикордонної служби України [6]. Однією з причин такого збігу є те, що у дослідженні А. С. Короля брала участь значна кількість керівників оперативно-розшукових підрозділів.

\section{Висновки та перспективи подальших} розвідок. Структурні елементи психологічної готовності керівника до управління організаційними змінами мають різний рівень сформованості - найбільш розвинені регулятивний, 
діяльнісний та мотиваційний компоненти, найменш розвинені когнітивний та особистісний компоненти. При цьому особистісний, когнітивний, мотиваційний та діяльнісний компоненти розвинені недостатньо, що підтверджується як дослідженням рівнів сформованості складових кожного з компонентів, так і розрахованими інтегративними показниками. Наявний стан психологічної готовності керівників оперативно-розшукових підрозділів до управління організаційними змінами у Державній прикордонній службі України свідчить про необхідність проведення додаткових заходів спрямованих на підвищення iï рівня.

Перспективними напрямами подальших наукових розвідок у зазначеному напрямі слід вважати розроблення науковообгрунтованого інструментарію який дозволив би підвищити рівень психологічної готовності керівників оперативно-розшукових підрозділів до управління організаційними змінами.

\section{Перелік використаних джерел:}

1. Психологічні засади організаційного розвитку : монографія / За наук. ред. Л. М. Карамушки. - Кіровоград : Імекс-ЛТД, 2013. - 206 с.

2. Карамушка Л. М. Психологія підготовки майбутніх менеджерів до управління змінами в організації: монографія / Л. М. Карамушка, М. В. Москальов. - К. Львів: Сполом, 2011, - 216 с.

3.Терещзенко K. В. Моделі організаційного розвитку в зарубіжній психології / К. В. Терещенко // Актуальні проблеми психології Т.1: Організаційна психологія. Економічна психологія. Соціальна психологія / За ред.
С. Д. Максименка, Л. М. Карамушки. - К.: A.C.K., 2009. - Ч. 23 - C. 26-32.

4. Карамушка Л. М., Філь О. А., Бондарчук О. І., Федосова Г. Л., Ковальчук О. С., Креденцер О. В., Терещенко К. В., Івкін В. М. Психологія діяльності організацій в умовах соціально-економічних змін (на матеріалі освітніх організацій): монографія. / За наук. ред. Л. М. Карамушки. - К.: „Педагогічна думка”, 2008. - 192 с.

5. Технологія психологічної підготовки персоналу організацій до роботи в умовах соціально-економічних змін (на матеріалі освітніх організацій): Навчальний посібник / За науковою редакцією професора Л. М. Карамушки. - К.: Наук. світ, 2008. - 230 с.

6. Король $\quad A$. C. Стан психологічної готовності керівників до управління організаційними змінами у Державній прикордонній службі України / А. С. Король // Науковий вісник Південноукраїнського національного педагогічного університету ім. К. Д. Ушинського (збірник наукових праць). - № 5-6. Одеса. ПНПУ ім. К. Д. Ушинського. 2013 - с. 52-62

7. Бондарчук О. I. Психологічна підготовка керівників освітніх організацій до діяльності в умовах змін: гуманістично-ціннісний підхід [Електронний ресурс] / О. I. Бондарчук // Вісник Чернігівського національного педагогічного університету. Серія : Психологічні науки. - 2014. - Вип. 121. - С. 38-43. - Режим доступу: http://nbuv.gov.ua/UJRN/VchdpuPH_2014_121_11

8. Філь O. А. Технологія психологічної підготовки керівників до забезпечення конкурентоздатності освітніх організацій в умовах змін [Електронний ресурс] / О. А. Філь // Вісник післядипломної освіти. - 2014. - Вип. 12. - C. 248-259. - Режим доступу: http://nbuv.gov.ua/UJRN/ Vpo_2014_12_25

9. Моросанова В. И., Коноз Е.М. Стилевая саморегуляция поведения человека // Вопросы психологии. - 2000. - №2. - С. 118-127.

10. Семиченко B. A. Опыт системно-структурного моделирования сложных объектов в психологопедагогических исследованиях / Валентина Анатольевна Семиченко // Проблеми сучасної педагогічної 
освіти : [зб. наук. ст.]. Педагогіка і психологія / Кримський держ. гуманіт. ін-т. - К., 2003. - Вип. 5. - С. $253-$ 266.

\section{References (Transsliteration):}

1. Psykholohichni zasady orhanizatsiinoho rozvytku : monohrafiia / Za nauk. red. L. M. Karamushky. Kirovohrad : Imeks-LTD, 2013. — 206 s.

2. Karamushka L. M. Psykholohiia pidhotovky maibutnikh menedzheriv do upravlinnia zminamy $\mathrm{v}$ orhanizatsii: monohrafiia / L. M. Karamushka, M. V. Moskalov. - K. Lviv: Spolom, 2011,-216 s.

3. Tereshchenko $K$. $V$. Modeli orhanizatsiinoho rozvytku v zarubizhnii psykholohii / K. V. Tereshchenko // Aktualni problemy psykholohii T.1: Orhanizatsiina psykholohiia. Ekonomichna psykholohiia. Sotsialna psykholohiia / Za red. S. D. Maksymenka, L. M. Karamushky. - K.: A.S.K., 2009. - Ch. 23 - S. 26-32.

4. Karamushka L. M., Fil O. A., Bondarchuk O. I., Fedosova H. L., Kovalchuk O. S., Kredentser O. V., Tereshchenko K. V., Ivkin V. M. Psykholohiia diialnosti orhanizatsii v umovakh sotsialno-ekonomichnykh zmin (na materiali osvitnikh orhanizatsii): monohrafiia. / Za nauk. red. L. M. Karamushky. - K.: „Pedahohichna dumka”, 2008. - 192 s.

5. Tekhnolohiia psykholohichnoi pidhotovky personalu orhanizatsii do roboty $\mathrm{v}$ umovakh sotsialnoekonomichnykh zmin (na materiali osvitnikh orhanizatsii): Navchalnyi posibnyk / Za naukovoiu redaktsiieiu profesora L. M. Karamushky. - K.: Nauk. svit, 2008. - 230 s.

6. Korol A. S. Stan psykholohichnoi hotovnosti kerivnykiv do upravlinnia orhanizatsiinymy zminamy u Derzhavnii prykordonnii sluzhbi Ukrainy / A. S. Korol // Naukovyi visnyk Pivdennoukrainskoho natsionalnoho pedahohichnoho universytetu im. K. D. Ushynskoho (zbirnyk naukovykh prats). - № 5-6. Odesa. PNPU im. K. D. Ushynskoho. 2013 - s. 52-62

7. Bondarchuk O. I. Psykholohichna pidhotovka kerivnykiv osvitnikh orhanizatsii do diialnosti $\mathrm{v}$ umovakh zmin: humanistychno-tsinnisnyi pidkhid [Elektronnyi resurs] / O. I. Bondarchuk // Visnyk Chernihivskoho natsionalnoho pedahohichnoho universytetu. Seriia : Psykholohichni nauky. - 2014. - Vyp. 121. - S. 38-43. - Rezhym dostupu: http://nbuv.gov.ua/UJRN/VchdpuPH_2014_121_11

8. Fil O. A. Tekhnolohiia psykholohichnoi pidhotovky kerivnykiv do zabezpechennia konkurentozdatnosti osvitnikh orhanizatsii $\mathrm{v}$ umovakh zmin [Elektronnyi resurs] / O. A. Fil // Visnyk pisliadyplomnoi osvity. - 2014. - Vyp. 12. - S. 248-259. - Rezhym dostupu: http:// nbuv.gov.ua/UJRN/Vpo_2014_12_25

9. Morosanova $\quad$ V. $\quad$ I., $\quad$ Konoz E.M. Stilevaya samoregulyatsiya povedeniya cheloveka // Voprosyi psihologii. - 2000. - №2. - S. 118-127.

10. Semichenko $\quad$ V. A. Opyit sistemno-strukturnogo modelirovaniya slozhnyih ob'ektov $\mathrm{v}$ psihologopedagogicheskih issledovaniyah / Valentina Anatolevna Semichenko // Problemi suchasnoyi pedagogichnoyi osviti : [zb. nauk. st.]. Pedagogika i psihologiya / Krimskiy derzh. gumanit. In-t. - K., 2003. - Vip. 5. - S. 253-266.

\section{Tuz, Olexandr}

Teacher of the department of special disciplines of Bogdan Khmelnitsky National Academy of the State Border Service of Ukraine, Khmelnitsky (Ukraine)

\section{RESULTS OF THE RESEARCH OF PSY- CHOLOGICAL READINESS OF OPERA- TIVE AND SUSCEPTIVE SUBSTANCES MANAGERS TO MANAGEMENT OF OR- GANIZATIONAL CHANGES}

\section{ABSTRACT}

The article presents the results of the empiri cal study of the level of psychological readiness of the heads of operational-search units of the State Border Guard Service of Ukraine to manager-organizational changes. Psychological readiness was studied by the indicators of the 
formation of cognitive, motivational, personal, activity and regulatory components.

Established significant gaps in theoretical knowledge of respondents, their abilities and skills in practical management of organizational changes, which determines the inadequate level of formation of the cognitive component. It was revealed that development of the motivation component is significantly influenced by the motivational immaturity of the respondents, as a result of which the loss of the basic value orientations, the unfavorable dynamics of the motivation, its extinction, the loss of interest in the profession, etc., becomes significant. It is found that a significant number of respondents do not consider the processes of organizational changes in the general direction of the development of border guarding of the European Union, which negatively affects the level of the activity component. It is educed that the vast majority of respondents possess personal qualities that assist high readiness to manage organizational changes. It is shown that generally respondents have a high level of a regulatory component development that provides conscious planning and programming of their own activities, adequacy in evaluating the results of actions, rapid orientation in a managerial situation, and so on. Three factors characterizing the basic typical manifestations of psychological readiness of respondents to manage changes and five types of its manifestation are distinguished. Dependence between operational experience of the heads of operational-search units and their level of psychological readiness to manage organizational changes is established. It is concluded that the structural elements of the psychological readiness of the manager to manage organizational changes have different levels of formation - the most developed are regulatory, activity and motivational components, the least developed cognitive and personal components. In this case, personal, cognitive, motivational and activity components are not developed enough and need further developing.

Key words: psychological readiness, organizational changes, the head of operational-search unit, operational experience.

\section{Туз Александр Сергеевич}

Преподаватель кафедры специиальных дисциилин Наџиональной академии Государственной пограничной службы Украины имени Богдана Хмельницкого, г. Хмельницкий (Украина)

\section{РЕЗУЛЬТАТЫ ИССЛЕДОВАНИЯ ПСИХОЛОГИЧЕСКОЙ ГОТОВНОСТИ РУКОВОДИТЕЛЕЙ ОПЕРАТИВНО- РОЗЫСКНЫХ ПОДРАЗДЕЛЕНИЙ К УПРАВЛЕНИЮ ОРГАНИЗАЦИОННЫМИ ИЗМЕНЕНИЯМИ}

Аннотация. В статье изложены результаты эмпирического исследования уровня психологической готовности руководителей оперативно-розыскных подразделений Государственной пограничной службы Украины к управлению организационными изменениями. Психологическая готовность изучалась по показателям развития ее когнитивного, мотива- 
ционного, личностного, деятельностного и регулятивного компонентов.

Выявлено, что существенные недостатки в теоретических знаниях респондентов, их умениях и навыках по практическому управлению организационными изменениями, решающим образом определяют недостаточный уровень сформированности когнитивного компонента. Установлено, что на степень развития мотивационного компонента существенно влияет мотивационная незрелость респондентов. В результате этого у респондентов не четко формируются базовые ценностные ориентиры, неблагоприятная динамика мотивации, ее затухание, потеря интереса к профессии и другие негативные качества подобного характера. Выявлено, что значительное количество респондентов не рассматривает процессы организационных изменений в общем русле развития пограничной охрани в Евросоюзе, что, в свою очередь, негативно влияет на уровень сформированности деятельностного компонента. У значительного большинства респондентов выявлены психологические свойства личности, которые содействуют высокой готовности к управлению организационными изменениями. Показано, что респондентов в целом характеризует высокий уровень развития регулятивного компонента. Высокий уровень регуляции обеспечивает сознательное планирование и программирование собственной деятельности, адекватность в оценке результатов собственных действий, быстрое ориентирование в управленческой ситуации и т.д.

Выделено три фактора, которые охватывают и характеризуют основные типовые проявления психологической готовности респондентов к управлению изменениями и пять форм их проявления. Установлена зависимость между служебным опытом руководителей оперативно-розыскных подразделений и уровнем их психологической готовности к управлению организационными изменениями.

Ключевые слова: психологическая готовность, организационные изменения, руководитель оперативно-розыскного подразделения, служебный опыт.

Дата отримання статті: 03.06.2018 Дата рекомендації до друку: 11.06.2018 Дата оприлюднення: 02.07.2018 